\title{
Review
}

\section{Issues Related to Recent Dengue Vaccine Development}

\author{
Eiji Konishi ${ }^{1,2,3^{*}}$ \\ Published online 6 August, 2011
}

\begin{abstract}
Dengue fever (DF) and dengue hemorrhagic fever (DHF) are mosquito-transmitted diseases of global importance. Despite significant research efforts, no approved vaccines or antiviral drugs against these diseases are currently available. This brief article reviews the status of dengue vaccine development, with particular emphasis on the vaccine strategies in more advanced stages of evaluation; these include traditional attenuation, chimerization and engineered attenuation. Several aspects of these vaccine design strategies, including concerns about vaccine candidates inducing infection-enhancing antibodies, are also presented.
\end{abstract}

Key words: Dengue, vaccine, neutralizing antibody, enhancing antibody

\section{INTRODUCTION}

Diseases caused by dengue virus infections are an increasing problem worldwide because of current globalization trends [1,2]. Despite intense research efforts over more than 30 years, no dengue vaccine is commercially available [3-10]. Approved antiviral drugs are also unavailable to treat dengue diseases. Currently, management of dengue virus infections relies on control measures targeting mosquito vectors. However, the emergence of mutant vector strains acquiring resistance against insecticides is an ongoing problem [11-13].

This paper briefly reviews efforts to develop a dengue vaccine. Currently, three vaccine strategies, namely traditional attenuation, chimerization and engineered attenuation, are in advanced stages of evaluation. After giving an overview on virus and gene structure, epidemiology, transmission and pathogenesis, several aspects of these vaccine strategies are presented. Other vaccine strategies, including virus-vectored, pseudo-infectious virus, DNA, inactivated and subunit vaccines developed for dengue viruses, have been described elsewhere [3-10].

\section{DENGUE VIRUS STRUCTURE AND GENOME}

Four types of dengue virus (dengue type 1 to 4 viruses; DENV1 to DENV4) belong to the genus Flavivirus of the family Flaviviridae [14]. The flavivirus virion consists of a nucleocapsid structure surrounded by a lipid bilayer containing an envelope (E) glycoprotein and a non-glycosylated membrane (M) protein. The nucleocapsid is composed of a capsid (C) protein and a single strand of positive-sense RNA. The E protein is the major surface protein with a role in receptor binding and membrane fusion, and it is known to constitute a major immunogen during flavivirus infection. Specifically, E protein contains most of the sites that react with neutralizing antibodies as well as many protective epitopes. The $\mathrm{M}$ protein is found in infected cells as a glycosylated precursor, premembrane (prM) protein. Dengue viral proteins, including these three structural proteins, are encoded by a single long translational open reading frame present in the genomic RNA. These viral proteins are synthesized in the order of $\mathrm{C}$, prM, E, followed by nonstructural proteins, NS1, NS2A, NS2B, NS3, NS4A, NS4B and NS5. The open reading frame is flanked by untranslated regions, the 5'-UTR and the 3'-UTR.

The similarity in antigenic structure among the four

\footnotetext{
${ }^{1}$ Division of Infectious Diseases, Department of International Health, Kobe University Graduate School of Health Sciences,

7-10-2 Tomogaoka, Suma-ku, Kobe 654-0412, Japan

${ }^{2}$ Division of Vaccinology, Center for Infectious Diseases, Kobe University Graduate School of Medicine,

7-5-1 Kusunoki-cho, Chuo-ku, Kobe 650-0017, Japan

${ }^{3}$ BIKEN Endowed Department of Dengue Vaccine Development, Faculty of Tropical Medicine, Mahidol University,

420/6 Ratchawithi Road, Ratchathewi, Bangkok 10400, Thailand

(Endowed from The Research Foundation for Microbial Diseases of Osaka University, Osaka, Japan to Research Institute for Microbial Diseases, Osaka University, Osaka, Japan)

"Corresponding author:

Department of International Health, Kobe University Graduate School of Health Sciences, 7-10-2 Tomogaoka, Suma-ku, Kobe 654-0142, Japan Tel/Fax: +81-78-796-4594

E-mail: ekon@kobe-u.ac.jp
} 
types of DENV is closely related to the characteristic features of the manifestations of dengue diseases. Most members of the genus Flavivirus can be grouped into eight antigenic complexes and four dengue viruses belong to the dengue virus serocomplex. These four dengue viruses are antigenically cross-reactive. Homology in the amino acid sequence of the $\mathrm{E}$ protein is approximately $70 \%$ among DENV1-4 [15].

\section{EPIDEMIOLOGY}

DENV1-4 are responsible for dengue fever (DF) and dengue hemorrhagic fever (DHF). These diseases occur throughout most of the tropical and subtropical areas of the world, with an estimated 50-100 million cases of DF and 250-500 thousand cases of DHF reported annually [1, 2]. DF and DHF are endemic in at least 100 countries and $>2.5$ billion people are at risk of infection.

In non-endemic areas, dengue infections may result from imported infectious cases [16]. An individual who has traveled and acquired an infection in an endemic area may return to their home country (non-endemic area) within an intrinsic period and then manifest symptoms. For example, DENVs do not currently circulate in Japan but approximately 1.7 million people travel overseas every year, increasing the risk of imported dengue infections [17]. According to a report from the National Institute of Infectious Diseases, around 100 virologically confirmed cases of dengue virus infection have been detected annually in recent years: however in 2010, 215 cases have been reported until the end of October [18]. This raises concerns that there are a large number of viremic patients in Japan and that these infecting viruses may be transmitted to domestic mosquitoes via mosquito bites during the summer season.

Phylogenetic analyses of the nucleotide sequences of the $\mathrm{E}$ coding region in the genome of isolated viruses demonstrate that several genotypes exist within each of the DENV types, DENV1-4 [19]. In addition to evolving within a particular environment, viruses may be transported from other areas and introduced into new environments because of the frequent movement of human hosts, both domestically and internationally. If the novel virus is better adapted to survive and propagate in its new environment, this virus may dominate over previously circulating viruses in the area. The replacement of a lineage, genotype or even a virus type has been reported in several areas [20-26].

\section{TRANSMISSION}

DENV exists in a transmission cycle between monkeys/ humans and mosquito vectors. In urban settings, humans have a role in the amplification of the viruses and their transmission cycles [27]. Although Aedes aegypti and Aedes albopictus are the major vectors for dengue virus transmission, the former is the more important vector because it has adapted to inhabit human dwellings. Patients can show serum virus titers up to $7 \log _{10} \mathrm{PFU} / \mathrm{ml}[28,29]$, which is high enough to infect mosquitoes when they ingest a blood meal (approximately $2 \mu \mathrm{l}$ ). In sylvatic settings, monkeys are considered an amplification host, transmitting the virus to mosquitoes.

Transovarial transmission is another mechanism by which the virus is maintained in nature. In susceptible mosquitoes, the first organ to allow virus replication is the midgut. The viral offspring released from the cells of the midgut into the body lumen may disseminate to most organs/ tissues of the mosquito, including the salivary gland, allowing direct transmission of the virus to humans. The virus may also be disseminated to the ovary of the mosquito, allowing transmission of the virus to their eggs. Therefore, the next generation may possess the virus without bloodsucking and may potentially be competent to transmit the virus to humans at first bite. This transmission mechanism has been demonstrated in the laboratory $[30,31]$ and in the field [32-35].

\section{PATHOGENESIS}

Most infections with dengue virus are asymptomatic. Clinical cases usually take a benign form (DF) and occasionally a severe form (DHF) [1, 2]. DF patients develop high fever, headache and muscle and joint pain, from which almost all cases recover, whereas DHF patients develop mainly plasma leakage and hemorrhagic manifestations, which may lead to shock. The case-fatality rate of DHF can exceed $20 \%$ without proper treatment, and a large proportion of hospitalized patients are children [36].

Several hypotheses have been proposed regarding the mechanism of increased disease severity from DF to DHF, which include both host and viral factors [1, 2, 37, 38]. As described above, the four DENVs are antigenically crossreactive. Many host factors are involved in the immune response after initial infection. Cross-reactive memory $\mathrm{T}$ cells are closely related to increased disease severity, and increased levels of cytokines and chemokines are also associated with the secondary infection. The genetic background of the host has also been proposed to be a factor involved in disease severity. Viral factors are attributed to the nucleotide sequence differences between viruses isolated from mild (DF) and severe (DHF) forms of the disease.

Although several mechanisms have been proposed for dengue pathogenesis, it is generally accepted that higher levels of viremia correspond to increased disease severity 
[39-41]. One of the mechanisms increasing the viremia level is antibody-dependent enhancement (ADE) of infection [42, 43], which is mediated by Fc gamma receptors (Fc $\gamma \mathrm{Rs}$ ) on monocytes/macrophages in the presence of cross-reactive non-neutralizing (enhancing) antibodies [44]. In contrast, neutralizing antibodies are widely believed to reduce viremia levels $[45,46]$. Thus, the viremia level depends on the balance of both neutralizing and enhancing antibodies and may determine the outcome of the disease; that is, by providing protection when neutralizing activities are higher than enhancing activities and conferring deterioration when enhancing activities are higher than neutralizing activities.

\section{VACCINES}

In the preclinical stages, the effectiveness of vaccine candidates has been evaluated by their ability to induce neutralizing antibodies in experimental animals and to reduce viremia levels in monkey models. Reduction of viremia is associated not only with reduced disease severity at an individual level but also with reduced efficiency of virus transmission to vector mosquitoes, thus contributing to reduced infection rates at the population level.

Currently, there are no commercially available dengue vaccines. However, several types of vaccine have been developed. Vaccines are considered the most effective preventive measure and, in addition to their potential contribution to reducing disease in endemic areas, vaccines are useful for protecting travelers from non-endemic to endemic countries.

Several lines of epidemiological evidence indicate that once an individual becomes infected with one type of DENV they are usually protected from subsequent infection with the same type of DENV (hereafter referred to as homotypic infection) [47, 48]. Therefore, humoral and cellular immune responses to homotypic viral antigens are considered responsible for protection from subsequent infections and are therefore the target for induction by protective vaccines.

\section{Viral proteins required for inducing protective immunity}

In flavivirus infections, the prM, E and NS1 proteins are considered important to induce protective immunity. In a mouse model, immunization with purified $\mathrm{E}$, or passive administration with monoclonal antibodies to $\mathrm{E}$, induces protection from lethal infection by the homologous virus, and the protection correlated with in vitro neutralizing activity [49-53]. Protective immunity was also rendered in mice by transferring monoclonal antibodies against prM [54] or NS1 [55, 56]: antibodies to prM have neutralizing activity in vitro, but antibodies to NS1 protect mice by a non-neutralizing mechanism. Based on this knowledge, the flavivirus prM, E, and/or NS1 genes have been used for developing genetically engineered dengue vaccines.

\section{Tetravalent formulation}

Immunization with a single type of dengue virus (monovalent vaccine) may present a risk of increased disease severity upon exposure to later infection with a different type of dengue virus in endemic areas where more than one dengue virus type exists, because non-neutralizing cross-reactive antibodies and cross-reactive memory $\mathrm{T}$ lymphocytes are potential mechanisms to cause dengue hemorrhagic fever. By contrast, people once infected with a certain type of dengue virus are usually protected from a subsequent homotypic infection [47, 48]. Therefore, a combination of vaccines that can induce immune responses against all four types of dengue virus (tetravalent vaccine) would be highly desirable for developing a safe and effective dengue vaccine [3-10].

\section{Vaccine development}

Traditional attenuation: Live attenuated vaccines are considered the most economical strategy and are therefore affordable in endemic areas comprised mainly of developing countries. Two tetravalent vaccine candidates have been separately developed; at the Mahidol University of Thailand and at the Walter Reed Army Institute of Research in the USA. Both vaccine viruses were developed by sequential passage through primary dog kidney cells, primary green monkey kidney cells or fetal rhesus lung cells. The vaccine candidate developed in Thailand has been licensed to Aventis Pasteur and that developed in the United States to GlaxoSmithKline.

Both attenuated vaccines have produced high seroconversion rates to all four serotypes after two or three doses in clinical trials [57-61], but concerns have been raised about the interference in virus replication, which is a potential problem that may occur when infectious vaccines are combined. Such interference is of particular concern in the development of dengue tetravalent vaccines, since imbalanced immune responses may cause increased disease severity [62]. Therefore, dosage formulations and/or vaccine schedules are considered important to adjust the immunogenicity of the four different live vaccine components [63, 64]. Because of this problem, and issues relating to reactogenicity, further clinical trials of the Aventis Pasteur vaccine candidate have been halted. The phase II trial for evaluating the GlaxoSmithKline vaccine using a protocol involving "formulation 17" has demonstrated less reactivity in volunteers [65]. Tetravalent neutralizing antibody responses were achieved in $63 \%$ of volunteers after two doses, and this 
vaccine candidate will proceed to a phase IIb trial.

Chimera: Advances in gene engineering technology have enabled the construction of chimeric viruses in which specific proteins from one virus are substituted for those of another virus. For dengue vaccine candidates, chimeric viruses have been constructed by exchanging the $\mathrm{prM} / \mathrm{E}$ genes of each of DENV1-4 for homologous genes of the yellow fever virus (YFV) strain 17D [66], or the DENV2 vaccine strain developed by Mahidol University included in the live-attenuated vaccine described above [67]. The former was licensed by Sanofi Pasteur and the latter by InViragen.

The chimeric tetravalent vaccine using YFV strain $17 \mathrm{D}$ as a backbone virus was well tolerated and produced high levels of neutralizing antibodies against DENV1-4 and/or viremia protection following challenge in preclinical evaluations using non-human primates [68-70] and a phase I clinical trial [71]. Phase II trials are currently underway in several countries and a phase III trial has started in Australia. Another chimeric tetravalent vaccine using a DENV2 vaccine strain as a backbone was also immunogenic and protective in AG129 mice [72]. A phase I trial is ongoing for this vaccine strain. Although the chimerization strategy appears to produce an ideal vaccine, the possibility of genetic recombination with virulent viruses remains a concern $[62,73]$.

Attenuation by deletion at the 3'-UTR: The 3'-UTR is critical for RNA replication. A 30-nucleotide deletion at the 3 ' site (nucleotides 172-143) resulted in attenuation but retained immunogenicity of DENV4 in monkeys [74]. This DENV4 430 vaccine was also well tolerated and immunogenic in humans $[75,76]$. The same strategy was successful in attenuating DENV1 [77, 78], but not DENV2 [79] or DENV3 [80]. For DENV2 and DENV3, a chimerization strategy similar to that described above was implemented: DENV4 $\triangle 30$ was used as the backbone virus and the prM and E genes of DENV2 and DENV3 were replaced with those of DENV4 430 . Experiments in monkeys indicated that the tetravalent formulation composed of these genetically engineered viruses was safe and induced balanced immune responses [81]. For DENV3, another strategy using a full-length infectious clone containing two deletions in the 3 '-UTR or the entire 3 '-UTR derived from DENV4 430 was implemented [82]. Moreover, DENV4 430 was further attenuated and proven to be safe and immunogenic in phase I clinical evaluations [83, 84]. These vaccine candidates were licensed by Panacea Biotec Ltd. and Biological E. Ltd. in India, Vabiotech in Vietnam and the Butantan Foundation in Brazil.

Viremia levels were low or undetectable in vaccinated volunteers, and the virus was not transmitted to mosquitoes.
This engineered attenuated vaccine candidate also showed less propagation in mosquitoes, potentially reducing transmission efficiency. However, a potential concern remained that immunocompromised individuals, who may be included in a large population of vaccinees, could experience highlevel viremia and that different geographical strains of mosquitoes may have different vector competences.

\section{Concerns for inducing enhancing antibodies}

Enhancing antibodies are one mechanism for increasing disease severity. In vitro studies have demonstrated that neutralizing antibodies that show no enhancing activity at low serum concentration show enhancing activities at high concentration [85]. The explanation for this phenomenon is that neutralizing activities overcome enhancing ones at low concentrations, although enhancing activities still exist. Specifically, neutralizing antibodies are usually measured by conventional neutralization tests using cells such as Vero or BHK cells. Since these cells do not have Fc $\gamma$ Rs, these tests only reflect the neutralizing activity in the serum samples. On the other hand, conventional ADE assays using Fc $\gamma$ R-bearing cells represent enhancing activities in a range of serum dilutions where the effect of neutralizing activity is negligible (subneutralizing doses).

This phenomenon is observed with immune sera and most monoclonal antibodies [86, 87]. Serum contains polyclonal antibodies comprising different antibody species. Some antibody species may have neutralizing activities, while others may have enhancing activities. Thus, the balance of neutralizing and enhancing activities is important for understanding the immune status of the host. However, conventional neutralization tests using cells without Fc $\gamma$ Rs can only detect neutralizing activities included in the serum sample. The evaluation of vaccine candidates has mostly been performed using neutralization tests rather than ADE assays. However, there are concerns that the current vaccine candidates capable of inducing neutralizing antibodies can also induce enhancing antibodies. It is highly probable that neutralizing antibodies constitute an immunological correlate against DENV, although this is still a subject of debate [45].

This balance of neutralizing and enhancing activities can be evaluated in a system that uses a BHK-21 cell line engineered to express Fc $\gamma \mathrm{R}$ [88] or a K562 cell line adapted to adhere to a plastic surface [89]. These cells can be used in an assay system similar to the conventional neutralization test. However, these cells can detect the enhancing, as well as the neutralizing, activities in the serum samples because of the Fc $\gamma \mathrm{R}$ on their surface. The balance of neutralizing and enhancing activities in the serum samples can also be measured in vivo, in a suitable animal model producing viremia following challenge. 


\section{Animal model}

Intracerebral inoculation of DENV has been the conventional method for evaluating the efficacy of candidate dengue vaccines in mice. In this method, the clinical symptoms related to encephalitis, and death, were monitored [90]. Adult mice are not usually susceptible to peripheral challenge with DENV, and therefore, fail to develop viremia following challenge [91-93]. A/J mice developed paralysis following intravenous infection with high-titer DENV2, but viremia was limited on day 2 after infection, as determined by the detection of viral RNA [94]. Severe combined immunodeficient mice engrafted with human cells susceptible to DENV infection produced viremia that could be detected by infectivity [95-98]. Other immunodeficient mouse models [99-107] have been developed, including AG129 mice deficient in interferon (IFN)- $\alpha / \beta$ and IFN- $\gamma$ receptors [108]. However, the major problem with these models is the lack of a normal immune response, making vaccine evaluation difficult, although they are useful for investigating the pathogenesis of dengue disease and for developing antiviral agents $[109,110]$.

Non-human primates are the most reliable animal models in which to evaluate the efficacy of candidate dengue vaccines, although they only develop low levels of viremia for short periods compared with the viremia that occurs in humans. The induction of neutralizing antibodies and the reduction in viremia levels can be used as indicators of vaccine efficacy, but monkeys exhibit only some of the symptoms of dengue disease observed in humans. Nevertheless, non-human primate models are still being developed and optimized as preclinical dengue vaccine evaluation systems [111, 112].

\section{CONCLUSION}

Dengue vaccine candidates that can induce neutralizing antibodies have been developed based on several strategies. Some of these vaccines are currently undergoing clinical trials. However, since neutralizing antibodies display enhancing activities at subneutralizing doses in vitro, there is a concern that dengue vaccine candidates that induce neutralizing antibodies may also induce enhancing activities. Thus, careful evaluation of candidate dengue vaccines is essential to monitor potential enhancing activities. Further optimization may be required to reduce such unwanted activities.

\section{ACKNOWLEDGMENTS}

This work was supported in part by grants-in-aid for Science and Technology Research Partnership for Sustain- able Development (SATREPS) from the Japan Science and Technology Agency/Japan International Cooperation Agency (JST/JICA).

\section{REFERENCES}

1. Halstead SB. Dengue. Lancet 2007; 370: 1644-1652.

2. Gubler DJ, Kuno G, Markoff L. Flaviviruses. In: Knipe DM, Howley PM, eds. Fields virology. 5th ed. Philadelphia: Lippincott Williams \& Willkins; 2007. p. 1153-1252.

3. Halstead SB, Vaughn DW. Dengue vaccines. In: Plotkin SA, Orenstein WA, Offit PA, eds. Vaccines. 5th ed. Maryland Heights: Saunders Elsevier; 2008. p. 1155-1161.

4. Widman DG, Frolov I, Mason PW. Third-generation flavivirus vaccines based on single-cycle, encapsidationdefective viruses. Adv Virus Res 2008; 72: 77-126.

5. Raviprakash K, Defang G, Burgess T, Porter K. Advances in dengue vaccine development. Hum Vaccin 2009; 5: 520528.

6. Durbin AP, Whitehead SS. Dengue vaccine candidates in development. Curr Top Microbiol Immunol 2010; 338: 129143.

7. Webster DP, Farrar J, Rowland-Jones S. Progress towards a dengue vaccine. Lancet Infect Dis 2009; 9: 678-687.

8. Miller N. Recent progress in dengue vaccine research and development. Curr Opin Mol Ther 2010; 12: 31-38.

9. Swaminathan S, Batra G, Khanna N. Dengue vaccines: state of the art. Expert Opin Ther Pat 2010; 20: 819-835.

10. Whitehead SS, Durbin AP. Prospects and challenges for dengue virus vaccine development. In: Hanley KA, Weaver SC, eds. Frontiers in Dengue Virus Research. Norfolk UK: Caister Academic Press; 2010. p. 221-237.

11. Cui F, Raymond M, Qiao CL. Insecticide resistance in vector mosquitoes in China. Pest Manag Sci 2006; 62: 10131022.

12. Llinás GA, Seccacini E, Gardenal CN, Licastro S. Current resistance status to temephos in Aedes aegypti from different regions of Argentina. Mem Inst Oswaldo Cruz 2010; 105: 113-116.

13. García GP, Flores AE, Fernández-Salas I, SaavedraRodríguez K, Reyes-Solis G, Lozano-Fuentes S, Guillermo Bond J, Casas-Martínez M, Ramsey JM, García-Rejón J, Domínguez-Galera M, Ranson H, Hemingway J, Eisen L, Black IV WC. Recent rapid rise of a permethrin knock down resistance allele in Aedes aegypti in México. PLoS Negl Trop Dis 2009; 3: e531.

14. Lindenbach BD, Thiel HJ, Rice CM. Flaviviridae: the viruses and their replication. In: Knipe DM, Howley PM, eds. Fields virology. 5th ed. Philadelphia: Lippincott Williams \& Willkins; 2007. p. 1101-1152.

15. Westaway EG, Blok J. Taxonomy and evolutionary relationships of flaviviruses. In: Gubler DJ, Kuno G, eds. Dengue and dengue hemorrhagic fever. New York: CABI Publishing; 1997. p. 147-173.

16. Gubler DJ. Arboviruses as imported disease agents: the need for increased awareness. Arch Virol Suppl 1996; 11: 
$21-32$.

17. The number of Japanese nationals leaving Japan, The Ministry of Justice. http: //www.moj.go.jp/ENGLISH/IB/ ib-01.html

18. Information of dengue virus infections, National Institute of Infectious Diseases. http://www.nih.go.jp/vir1/NVL/ dengue.htm

19. Bennett SN. Evolutionary dynamics of dengue virus. In: Hanley KA, Weaver SC, eds. Frontiers in dengue virus research. Norfolk, UK: Caister Academic Press; 2010. p. $157-172$.

20. Salda LT, Parquet MD, Matias RR, Natividad FF, Kobayashi $\mathrm{N}$, Morita K. Molecular epidemiology of dengue 2 viruses in the Philippines: genotype shift and local evolution. Am J Trop Med Hyg 2005; 73: 796-802.

21. Zhang C, Mammen MP Jr, Chinnawirotpisan P, Klungthong C, Rodpradit P, Monkongdee P, Nimmannitya $\mathrm{S}$, Kalayanarooj S, Holmes EC. Clade replacements in dengue virus serotypes 1 and 3 are associated with changing serotype prevalence. J Virol 2005; 79: 15123-15130.

22. Myat Thu H, Lowry K, Jiang L, Hlaing T, Holmes EC, Aaskov J. Lineage extinction and replacement in dengue type 1 virus populations are due to stochastic events rather than to natural selection. Virology 2005; 336: 163-172.

23. Aquino JD, Tang WF, Ishii R, Ono T, Eshita Y, Aono H, Makino Y. Molecular epidemiology of dengue virus serotypes 2 and 3 in Paraguay during 2001-2006: the association of viral clade introductions with shifting serotype dominance. Virus Res 2008; 137: 266-270.

24. Shu PY, Su CL, Liao TL, Yang CF, Chang SF, Lin CC, Chang MC, Hu HC, Huang JH. Molecular characterization of dengue viruses imported into Taiwan during 2003-2007: geographic distribution and genotype shift. Am J Trop Med Hyg 2009; 80: 1039-1046.

25. Kumar SR, Patil JA, Cecilia D, Cherian SS, Barde PV, Walimbe AM, Yadav PD, Yergolkar PN, Shah PS, Padbidri VS, Mishra AC, Mourya DT. Evolution, dispersal and replacement of American genotype dengue type 2 viruses in India (1956-2005): selection pressure and molecular clock analyses. J Gen Virol 2010; 91: 707-720.

26. Li DS, Liu W, Guigon A, Mostyn C, Grant R, Aaskov J. Rapid displacement of dengue virus type 1 by type 4, Pacific region, 2007-2009. Emerg Infect Dis 2010; 16: 123-125.

27. Weaver SC. Host range, amplification and arboviral disease emergence. Arch Virol Suppl 2005; 19: 33-44.

28. Yamada K, Takasaki T, Nawa M, Kurane I. Virus isolation as one of the diagnostic methods for dengue virus infection. J Clin Virol 2002; 24: 203-209.

29. Ooi Y, Hayashi A, Aoki H, Eda J, Hamada M, Imura S, et al. Viral Titers in the Sera of Dengue Patients among Travelers at the Quarantine Station of Kansai International Airport. Jpn J Infect Dis 2008; 6: 329-330.

30. Rosen L, Shroyer DA, Tesh RB, Freier JE, Lien JC. Transovarial transmission of dengue viruses by mosquitoes: Aedes albopictus and Aedes aegypti. Am J Trop Med Hyg 1983; 32: 1108-1119.
31. Rosen L. Mechanism of vertical transmission of the dengue virus in mosquitoes. C R Acad Sci III 1987; 304: 347-350.

32. Günther J, Martínez-Muñoz JP, Pérez-Ishiwara DG, SalasBenito J. Evidence of vertical transmission of dengue virus in two endemic localities in the state of Oaxaca, Mexico. Intervirology 2007; 50: 347-352.

33. Angel B, Joshi V. Distribution and seasonality of vertically transmitted dengue viruses in Aedes mosquitoes in arid and semi-arid areas of Rajasthan, India. J Vector Borne Dis 2008; 45: 56-59.

34. Zeidler JD, Acosta PO, Barrêto PP, Cordeiro Jda S. Dengue virus in Aedes aegypti larvae and infestation dynamics in Roraima, Brazil. Rev Saude Publica 2008; 42: 986-991.

35. Guedes DR, Cordeiro MT, Melo-Santos MA, Magalhaes T, Marques E, Regis L, Furtado AF, Ayres CF. Patient-based dengue virus surveillance in Aedes aegypti from Recife, Brazil. J Vector Borne Dis 2010; 47: 67-75.

36. World Health Organization. March 2009, Fact sheet $N^{\circ} 117$. Dengue and Dengue haemorrhagic fever. [Online.] http://www.who.int/mediacentre/factsheets/fs117/en/

37. Green S, Rothman A. Immunopathological mechanisms in dengue and dengue hemorrhagic fever. Curr Opin Infect Dis 2006; 19: 429-436.

38. Rico-Hesse R. Dengue virus markers of virulence and pathogenicity. Future Virol 2009; 4: 581.

39. Vaughn DW, Green S, Kalayanarooj S, et al. Dengue viremia titer, antibody response pattern, and virus serotype correlate with disease severity. J Infect Dis 2000; 181: 2-9.

40. Libraty DH, Endy TP, Houng HS, et al. Differing influences of virus burden and immune activation on disease severity in secondary dengue-3 virus infections. $J$ Infect Dis 2002; 185: 1213-1221.

41. Stephenson JR. Understanding dengue pathogenesis: implications for vaccine design. Bull World Health Organ 2005; 83: 308-314.

42. Halstead SB, O'Rourke EJ. Antibody-enhanced dengue virus infection in primate leukocytes. Nature 1977; 265: 739-741.

43. Kliks SC, Nisalak A, Brandt WE, Wahl L, Burke DS. Antibody-dependent enhancement of dengue virus growth in human monocytes as a risk factor for dengue hemorrhagic fever. Am J Trop Med Hyg 1989; 40: 444-451.

44. Kurane I, Mady BJ, Ennis FA. Antibody-dependent enhancement of dengue virus infection. Rev Med Virol 1991; 1: 211-221.

45. Hombach J, Cardosa ML, Sabchareon A, Vaughn DW, Barrett AD. Scientific consultation on immunological correlates of protection induced by dengue vaccines report from a meeting held at the World Health Organization 1718 November 2005. Vaccine 2007; 25: 4130-4139.

46. Pierson TC, Diamond MS. Molecular mechanisms of antibody-mediated neutralisation of flavivirus infection. Expert Rev Mol Med 2008; 10: e12.

47. Sabin AB. Research on Dengue during World War II. Am J Trop Med Hyg 1952; 1: 30-50.

48. Wikramaratna PS, Simmons CP, Gupta S, Recker M. 
The effects of tertiary and quaternary infections on the epidemiology of dengue. PLoS One 2010; 5. pii: e12347.

49. Mathews JH, Roehrig JT. Elucidation of the topography and determination of the protective epitopes on the $\mathrm{E}$ glycoprotein of Saint Louis encephalitis virus by passive transfer with monoclonal antibodies. J Immunol 1984; 132: 1533-1537.

50. Gould EA, Buckley A, Barrett AD, Cammack N. Neutralizing $(54 \mathrm{~K})$ and non-neutralizing (54K and $48 \mathrm{~K}$ ) monoclonal antibodies against structural and non-structural yellow fever virus proteins confer immunity in mice. J Gen Virol 1986; 67: 591-595.

51. Kaufman BM, Summers PL, Dubois DR, Eckels KH. Monoclonal antibodies against dengue 2 virus Eglycoprotein protect mice against lethal dengue infection. Am J Trop Med Hyg 1987; 36: 427-434.

52. Kimura-Kuroda J, Yasui K. Protection of mice against Japanese encephalitis virus by passive administration with monoclonal antibodies. J Immunol 1988; 141: 3606-3610.

53. Mason PW, Dalrymple JM, Gentry MK, et al. Molecular characterization of a neutralizing domain of the Japanese encephalitis virus structural glycoprotein. J Gen Virol 1989; 70: 2037-2049.

54. Kaufman BM, Summers PL, Dubois DR, et al. Monoclonal antibodies for dengue virus prM glycoprotein protect mice against lethal dengue infection. Am J Trop Med Hyg 1989; 41: 576-580.

55. Schlesinger JJ, Brandriss MW, Walsh EE. Protection against 17D yellow fever encephalitis in mice by passive transfer of monoclonal antibodies to the nonstructural glycoprotein gp48 and by active immunization with gp48. J Immunol 1985; 135: 2805-2809.

56. Henchal EA, Henchal LS, Schlesinger JJ. Synergistic interactions of anti-NS1 monoclonal antibodies protect passively immunized mice from lethal challenge with dengue 2 virus. J Gen Virol 1988; 69: 2101-2107.

57. Sabchareon A, Lang J, Chanthavanich P, Yoksan S, Forrat R, Attanath P, et al. Safety and immunogenicity of tetravalent live-attenuated dengue vaccines in Thai adult volunteers: role of serotype concentration, ratio, and multiple doses. Am J Trop Med Hyg 2002; 66: 264-272.

58. Sabchareon A, Lang J, Chanthavanich P, Yoksan S, Forrat R, Attanath P, et al. Safety and immunogenicity of a three dose regimen of two tetravalent live-attenuated dengue vaccines in five- to twelve-year-old Thai children. Pediatr Infect Dis J 2004; 23: 99-109.

59. Edelman R, Wasserman SS, Bodison SA, Putnak RJ, Eckels KH, Tang D, et al. Phase I trial of 16 formulations of a tetravalent live-attenuated dengue vaccine. Am J Trop Med Hyg 2003; 69(6 Suppl): 48-60.

60. Sun W, Edelman R, Kanesa-Thasan N, Eckels KH, Putnak JR, King AD, Houng HS, Tang D, Scherer JM, Hoke CH $\mathrm{Jr}$, Innis BL. Vaccination of human volunteers with monovalent and tetravalent live-attenuated dengue vaccine candidates. Am J Trop Med Hyg 2003; 69(6 Suppl): 24-31.

61. Simasathien S, Thomas SJ, Watanaveeradej V, Nisalak A, Barberousse C, Innis BL, Sun W, Putnak JR, Eckels KH,
Hutagalung Y, Gibbons RV, Zhang C, De La Barrera R, Jarman RG, Chawachalasai W, Mammen MP Jr. Safety and immunogenicity of a tetravalent live-attenuated dengue vaccine in flavivirus naive children. Am J Trop Med Hyg 2008; 78: 426-433.

62. Stephenson JR. Understanding dengue pathogenesis: implications for vaccine design. Bull World Health Organ 2005; 83: 308-314.

63. Kitchener S, Nissen M, Nasveld P, Forrat R, Yoksan S, Lang $\mathrm{J}$, et al. Immunogenicity and safety of two liveattenuated tetravalent dengue vaccine formulations in healthy Australian adults. Vaccine 2006; 24: 1238-1241.

64. Guy B, Barban V, Mantel N, Aguirre M, Gulia S, Pontvianne $\mathrm{J}$, et al. Evaluation of interferences between dengue vaccine serotypes in a monkey model. Am J Trop Med Hyg 2009; 80: 302-311.

65. Sun W, Cunningham D, Wasserman SS, Perry J, Putnak JR, Eckels KH, Vaughn DW, Thomas SJ, Kanesa-Thasan $\mathrm{N}$, Innis BL, Edelman R. Phase 2 clinical trial of three formulations of tetravalent live-attenuated dengue vaccine in flavivirus-naïve adults. Hum Vaccin 2009; 5: 33-40.

66. Chambers TJ, Nestorowicz A, Mason PW, Rice CM. Yellow fever/Japanese encephalitis chimeric viruses: construction and biological properties. J Virol 1999; 73: 30953101.

67. Huang CY, Butrapet S, Pierro DJ, Chang GJ, Hunt AR, Bhamarapravati N, Gubler DJ, Kinney RM. Chimeric dengue type 2 (vaccine strain PDK-53)/dengue type 1 virus as a potential candidate dengue type 1 virus vaccine. J Virol 2000; 74: 3020-3028.

68. Guirakhoo F, Arroyo J, Pugachev KV, Miller C, Zhang ZX, Weltzin R, Georgakopoulos K, Catalan J, Ocran S, Soike K, Ratterree M, Monath TP. Construction, safety, and immunogenicity in nonhuman primates of a chimeric yellow fever-dengue virus tetravalent vaccine. J Virol 2001; 75: 7290-7304.

69. Guirakhoo F, Pugachev K, Arroyo J, Miller C, Zhang ZX, Weltzin R, Georgakopoulos K, Catalan J, Ocran S, Draper $\mathrm{K}$, Monath TP. Viremia and immunogenicity in nonhuman primates of a tetravalent yellow fever-dengue chimeric vaccine: genetic reconstructions, dose adjustment, and antibody responses against wild-type dengue virus isolates. Virology 2002; 298: 146-159.

70. Guirakhoo F, Pugachev K, Zhang Z, Myers G, Levenbook I, Draper K, et al. Safety and efficacy of chimeric yellow Fever-dengue virus tetravalent vaccine formulations in nonhuman primates. J Virol 2004; 78: 4761-4775.

71. Guirakhoo F, Kitchener S, Morrison D, Forrat R, McCarthy K, Nichols R, et al. Live attenuated chimeric yellow fever dengue type 2 (ChimeriVax-DEN2) vaccine: Phase I clinical trial for safety and immunogenicity: effect of yellow fever pre-immunity in induction of cross neutralizing antibody responses to all 4 dengue serotypes. Hum Vaccin 2006; 2: 60-67.

72. Huang CY, Butrapet S, Tsuchiya KR, Bhamarapravati N, Gubler DJ, Kinney RM. Dengue 2 PDK-53 virus as a chimeric carrier for tetravalent dengue vaccine develop- 
ment. J Virol 2003; 77: 11436-11447.

73. Seligman SJ, Gould EA. Live flavivirus vaccines: reasons for caution. Lancet 2004; 363: 2073-2075.

74. Men R, Bray M, Clark D, Chanock RM, Lai CJ. Dengue type 4 virus mutants containing deletions in the 3 ' noncoding region of the RNA genome: analysis of growth restriction in cell culture and altered viremia pattern and immunogenicity in rhesus monkeys. J Virol 1996; 70: 3930-3937.

75. Durbin AP, Karron RA, Sun W, Vaughn DW, Reynolds MJ, Perreault JR, Thumar B, Men R, Lai CJ, Elkins WR, Chanock RM, Murphy BR, Whitehead SS. Attenuation and immunogenicity in humans of a live dengue virus type- 4 vaccine candidate with a 30 nucleotide deletion in its 3'-untranslated region. Am J Trop Med Hyg 2001; 65: 405-413.

76. Durbin AP, Whitehead SS, McArthur J, Perreault JR, Blaney JE Jr, Thumar B, Murphy BR, Karron RA. rDEN4delta30, a live attenuated dengue virus type 4 vaccine candidate, is safe, immunogenic, and highly infectious in healthy adult volunteers. J Infect Dis 2005; 191: 710-718.

77. Whitehead SS, Falgout B, Hanley KA, Blaney JE Jr, Markoff L, Murphy BR. A live, attenuated dengue virus type 1 vaccine candidate with a 30 -nucleotide deletion in the $3^{\prime}$ untranslated region is highly attenuated and immunogenic in monkeys. J Virol 2003; 77: 1653-1657.

78. Durbin AP, McArthur J, Marron JA, Blaney JE Jr, Thumar B, Wanionek K, Murphy BR, Whitehead SS. The live attenuated dengue serotype 1 vaccine rDEN1Delta30 is safe and highly immunogenic in healthy adult volunteers. Hum Vaccin 2006; 2: 167-173.

79. Blaney JE Jr, Hanson CT, Hanley KA, Murphy BR, Whitehead SS. Vaccine candidates derived from a novel infectious cDNA clone of an American genotype dengue virus type 2. BMC Infect Dis 2004; 4: 39.

80. Blaney JE Jr, Hanson CT, Firestone CY, Hanley KA, Murphy BR, Whitehead SS. Genetically modified, live attenuated dengue virus type 3 vaccine candidates. Am J Trop Med Hyg 2004; 71: 811-821.

81. Blaney JE Jr, Matro JM, Murphy BR, Whitehead SS. Recombinant, live-attenuated tetravalent dengue virus vaccine formulations induce a balanced, broad, and protective neutralizing antibody response against each of the four serotypes in rhesus monkeys. J Virol 2005; 79: 5516-5528.

82. Blaney JE Jr, Sathe NS, Goddard L, Hanson CT, Romero TA, Hanley KA, Murphy BR, Whitehead SS. Dengue virus type 3 vaccine candidates generated by introduction of deletions in the $3^{\prime}$ untranslated region (3'-UTR) or by exchange of the DENV-3 3'-UTR with that of DENV-4. Vaccine 2008; 26: 817-828.

83. McArthur JH, Durbin AP, Marron JA, Wanionek KA, Thumar B, Pierro DJ, Schmidt AC, Blaney JE Jr, Murphy BR, Whitehead SS. Phase I clinical evaluation of rDEN4Delta30-200,201: a live attenuated dengue 4 vaccine candidate designed for decreased hepatotoxicity. Am J Trop Med Hyg 2008; 79: 678-684.

84. Wright PF, Durbin AP, Whitehead SS, Ikizler MR, Henderson S, Blaney JE, Thumar B, Ankrah S, Rock MT,
McKinney BA, Murphy BR, Schmidt AC. Phase 1 trial of the dengue virus type 4 vaccine candidate rDEN4 \{Delta\}304995 in healthy adult volunteers. Am J Trop Med Hyg 2009; 81: 834-841.

85. Halstead SB. Neutralization and antibody-dependent enhancement of dengue viruses. Adv Virus Res 2003; 60: 421-467.

86. Morens DM, Halstead SB, Marchette NJ. Profiles of antibody-dependent enhancement of dengue virus type 2 infection. Microb Pathog 1987; 3: 231-237.

87. Yamanaka A, Kosugi S, Konishi E. Infection-enhancing and -neutralizing activities of mouse monoclonal antibodies against dengue type 2 and 4 viruses are controlled by complement levels. J Virol 2008; 82: 927-937.

88. Moi ML, Lim CK, Kotaki A, Takasaki T, Kurane I. Development of an antibody-dependent enhancement assay for dengue virus using stable BHK-21 cell lines expressing Fc gammaRIIA. J Virol Methods 2010; 163: 205-209.

89. Konishi E, Tabuchi Y, Yamanaka A. A simple assay system for infection-enhancing and -neutralizing antibodies to dengue type 2 virus using layers of semi-adherent K562 cells. J Virol Methods 2010; 163: 360-367.

90. Raut CG, Deolankar RP, Kolhapure RM, Goverdhan MK. Susceptibility of laboratory-bred rodents to the experimental infection with dengue virus type 2. Acta Virol 1996; 40: 143-146.

91. Paes MV, Pinhao AT, Barreto DF, et al. Liver injury and viremia in mice infected with dengue-2 virus. Virology 2005; 338: 236-246.

92. Chen HC, Lai SY, Sung JM, et al. Lymphocyte activation and hepatic cellular infiltration in immunocompetent mice infected by dengue virus. J Med Virol 2004; 73: 419-431.

93. Chen HC, Hofman FM, Kung JT, Lin YD, Wu-Hsieh BA. Both virus and tumor necrosis factor alpha are critical for endothelium damage in a mouse model of dengue virusinduced hemorrhage. J Virol 2007; 81: 5518-5526.

94. Huang KJ, Li SY, Chen SC, et al. Manifestation of thrombocytopenia in dengue-2-virus-infected mice. J Gen Virol 2000; 81: 2177-2182.

95. Wu SJ, Hayes CG, Dubois DR, et al. Evaluation of the severe combined immunodeficient (SCID) mouse as an animal model for dengue viral infection. Am J Trop Med Hyg 1995; 52: 468-476.

96. Lin YL, Liao CL, Chen LK, et al. Study of Dengue Virus Infection in SCID Mice Engraftedwith Human K562 Cells. J Virol 1998; 72: 9729-9737.

97. An J, Kimura-Kuroda J, Hirabayashi Y, Yasui K. Development of a novel mouse model for dengue virus infection. Virology 1999; 263: 70-77.

98. Blaney JE Jr, Johnson DH, Manipon GG, et al. Genetic basis of attenuation of dengue virus type 4 small plaque mutants with restricted replication in suckling mice and in SCID mice transplanted with human liver cells. Virology 2002; 300: 125-139.

99. Bente DA, Melkus MW, Garcia JV, Rico-Hesse R. Dengue fever in humanized NOD/SCID mice. J Virol 2005; 79: 13797-13799. 
100. Kuruvilla JG, Troyer RM, Devi S, Akkina R. Dengue virus infection and immune response in humanized RAG2-/- $\gamma \mathrm{c}-/$ -(RAG-hu) mice. Virology 2007; 369: 143-152.

101. Shresta S, Sharar KL, Prigozhin DM, Beatty PR, Harris E. Murine Model for Dengue Virus-Induced Lethal Disease with Increased Vascular Permeability. J Virol 2006; 80: 10208-10217.

102. Mota J, Rico-Hesse R. Humanized mice show clinical signs of dengue fever according to infecting virus genotype. J Virol 2009; 83: 8638-8645.

103. Williams KL, Zompi S, Beatty PR, Harris E. A mouse model for studying dengue virus pathogenesis and immune response. Ann N Y Acad Sci 2009; 1171 Suppl 1: E12E23.

104. Wu-Hsieh BA, Yen YT, Chen HC. Dengue hemorrhage in a mouse model. Ann N Y Acad Sci 2009; 1171 Suppl 1: E42-E47.

105. Jaiswal S, Pearson T, Friberg H, Shultz LD, Greiner DL, Rothman AL, Mathew A. Dengue virus infection and virus-specific HLA-A2 restricted immune responses in humanized NOD-scid IL2rgammanull mice. PLoS One 2009; 4: e7251.

106. Zellweger RM, Prestwood TR, Shresta S. Enhanced infection of liver sinusoidal endothelial cells in a mouse model of antibody-induced severe dengue disease. Cell Host Microbe 2010; 7: 128-139.

107. Tan GK, Ng JK, Trasti SL, Schul W, Yip G, Alonso S. A non mouse-adapted dengue virus strain as a new model of severe dengue infection in AG129 mice. PLoS Negl Trop Dis 2010; 4: e672.

108. Johnson AJ, Roehrig JT. New mouse model for dengue virus vaccine testing. J Virol 1999; 73: 783-786.

109. Bente DA, Rico-Hesse R. Models of dengue virus infection. Drug Discov Today Dis Models 2006; 3: 97-103.

110. Yauch LE, Shresta S. Mouse models of dengue virus infection and disease. Antiviral Res 2008; 80: 87-93.

111. Martín J, Hermida L, Castro J, Lazo L, Martínez R, Gil L, Romero Y, Puente P, Zaragoza S, Cosme K, Guzmán MG, Cardosa J, Guillén G. Viremia and antibody response in green monkeys (Chlorocebus aethiops sabaeus) infected with dengue virus type 2: a potential model for vaccine testing. Microbiol Immunol 2009; 53: 216-223.

112. Onlamoon N, Noisakran S, Hsiao HM, Duncan A, Villinger F, Ansari AA, Perng GC. Dengue virus-induced hemorrhage in a nonhuman primate model. Blood 2010; 115: 1823-1834. 